\title{
How is the insulin content regulated in nondiabetic hyperinsulinaemic, insulin resistant states? Study of spontaneously hypertensive rats
}

\author{
Jack L. Leahy ${ }^{1}$, Chuan Chen ${ }^{1}$, Christopher J. Rhodes ${ }^{2}$ \\ ${ }^{1}$ Division of Endocrinology, Diabetes and Metabolism, University of Vermont College of Medicine, Burlington, USA \\ ${ }^{2}$ Departments of Internal Medicine and Pharmacology, University of Texas Southwestern Medical Center, Dallas, USA
}

The successful adaption to insulin resistant states occurs through a beta-cell hyperfunction [1]. The traditional explanation invokes the well-known feedback loop with glycaemia: it is generally presumed that a minor degree of hyperglycaemia elicits the increased insulin secretion. We previously studied insulin resistant hyperinsulinaemic spontaneously hypertensive rats (SHR), and found their basal and post stimulation glycaemia levels were identical to normally insulin sensitive Wistar Kyoto rats (WK) [2]. The mechanism of the hyperinsulinaemia was a subnormal glucose set-point $\left(\mathrm{ED}_{50}\right)$ for insulin secretion. The same observation has been made in pregnant rats, another insulin resistant state [3, 4]. Thus, the compensation to insulin resistance appears to entail an altered beta-cell glucose sensing system, with the result being normoglycaemia. A similar situation may occur in humans since a hypersecretion of insulin has been observed in obese subjects in tandem with glycaemia values that exactly matched nonobese control subjects over a $24 \mathrm{~h}$ period [5].

The current report has addressed what happens to the beta-cell insulin stores in SHR. We have noted a close parallel relationship between the pancreas insulin content and insulin secretory responses in nondiabetic and diabetic rats [6,7], suggesting the insulin stores exert a regulatory influence over insulin secretion. In that case, an adaptive mechanism must exist in SHR that counterbalances the insulin hypersecretion. Confirming that idea, Iwase reported the pancreas insulin content of SHR rats was twice that of age-matched WK rats with no difference in the pancreas beta-cell mass [8]. However, current knowledge

Corresponding author: Dr. J. Leahy, University of Vermont College of Medicine, Given C331, Burlington, VT 05405, USA Abbreviations: SHR, Spontaneously hypertensive rats; WK, Kyoto rats; IRI, insulin immunoreactivity. provides little insight into the mechanism. Insulin content is viewed as a balance of synthesis, secretion and lysosomal degradation (so-called crinophagy). All three are glucose-responsive. Hyperglycaemia induces a near-instantaneous increase of insulin secretion and post-transcriptional proinsulin synthesis [9] followed by adaptive changes of proinsulin gene transcription and intracellular degradation after several hours $[10,11]$. The adaptive mechanism in SHR is unclear since glycaemia is unchanged. Proinsulin synthesis is increased in pregnant rats [12] and we expected to find increased transcriptional or translational production or both of proinsulin as another manifestation of the enhanced beta-cell glucose sensitivity. Instead, as described in this report, proinsulin synthesis was unchanged in SHR. Also, intracellular granule degradation was not obviously changed within the limits of current technology for its measurement. Thus, our results raise the possibility that regulatory factors exist for the insulin content beyond the traditional triad, and are operative in insulin resistant states.

Increased islet insulin content in SHR. We investigated normoglycaemic 12 week-old SHR which our previous study showed had twice normal plasma insulin levels compared with age-matched WK rats [2]. An additional finding was the insulin secretion at $7.8 \mathrm{mmol} / \mathrm{l}$ glucose (glycaemia level of a normal rat) from SHR isolated islets was twice that of WK islets when the DNA contents were identical, confirming the hyperinsulinaemia stemmed from hyperfunctioning beta cells [2]. We now have found that SHR islets have a greater insulin content than WK islets $(80 \pm 8$ $\mathrm{ng} /$ islet SHR vs $59 \pm 5 \mathrm{ng}$ /islet $\mathrm{WK}, n=7, p<0.05$ ) which confirms the report of Iwase in whole pancreas [8] that a mechanism exists in SHR that counterbalances (even surpasses) the insulin hypersecretion and preserves the insulin content. 


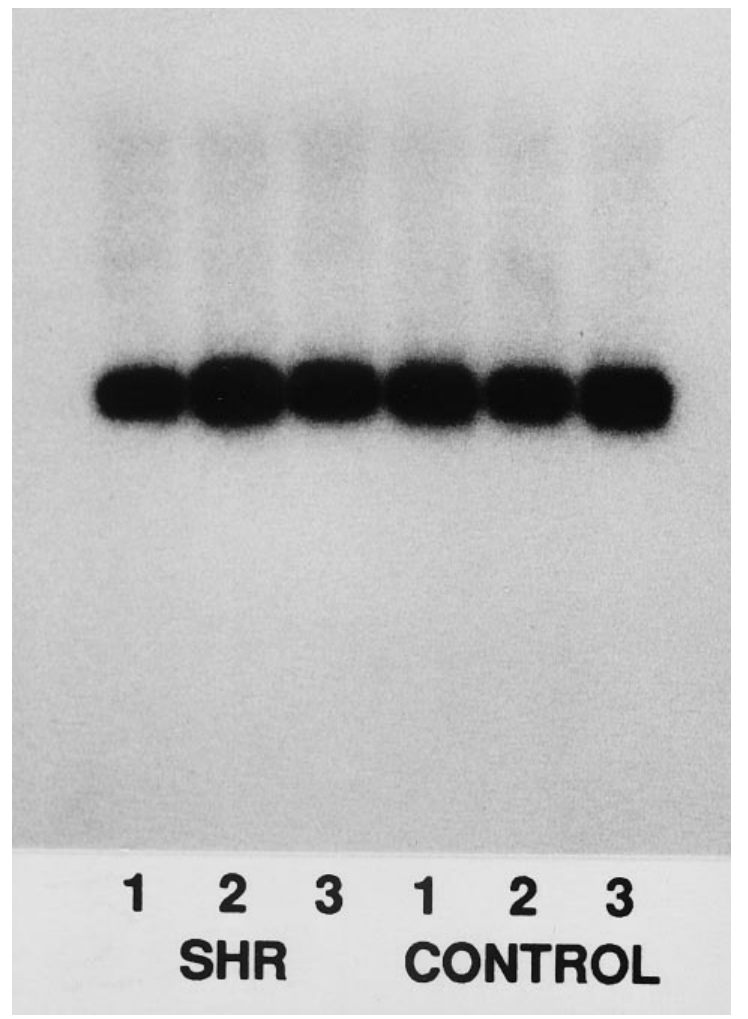

Fig. 1. Proinsulin mRNA in isolated islets of SHR and WK rats. Lanes were loaded with $2.5 \mu \mathrm{g}$ total islet RNA from $3 \mathrm{sep}$ arate SHR and $3 \mathrm{WK}$ rats followed by electrophoresis on a $1 \%$ agarose $/ 6 \%$ formaldehyde gel and transfer onto a nylon membrane. After prehybridization with denatured salmon sperm DNA, membranes were hybridized overnight at $42^{\circ} \mathrm{C}$ with a $\left.{ }^{32} \mathrm{P}\right]-\mathrm{CTP}$ radiolabelled riboprobe for rat proinsulin I (gift from L.G. Moss, New England Medical Center, Boston, Mass., USA), washed with high stringency conditions, and visualized by autoradiography

In vitro proinsulin synthesis in SHR. We expected to find increased proinsulin synthesis in SHR because of that finding having been made in pregnant rats [12]. Proinsulin gene expression was measured in freshly isolated SHR and WK islets using a previously described Northern blot method [13]. Figure 1 shows there was no difference between three SHR and three WK rats. An additional two pairs were studied: the total group showed no difference between SHR and WK islets (SHR $109 \pm 14 \%$ of WK, $n=5)$.

Proinsulin synthesis was quantified by $\left[{ }^{35} \mathrm{~S}\right] \mathrm{me}$ thionine incorporation as described previously [13, 14]. Glucose concentrations of 2.8 and $16.7 \mathrm{mmol} / \mathrm{l}$ were used to investigate whether the glucose setpoint was lowered in SHR, akin to insulin secretion. As shown in Figure 2, there was no difference in the band intensities between SHR and WK islets at either glucose concentration. In five pairs of animals, the results were $61 \pm 26 \%$ at $2.8 \mathrm{mmol} / \mathrm{l}$ glucose and $90 \pm 30 \%$ at $16.7 \mathrm{mmol} / \mathrm{l}$ glucose for SHR relative to WK ( $p=$ NS for both values).

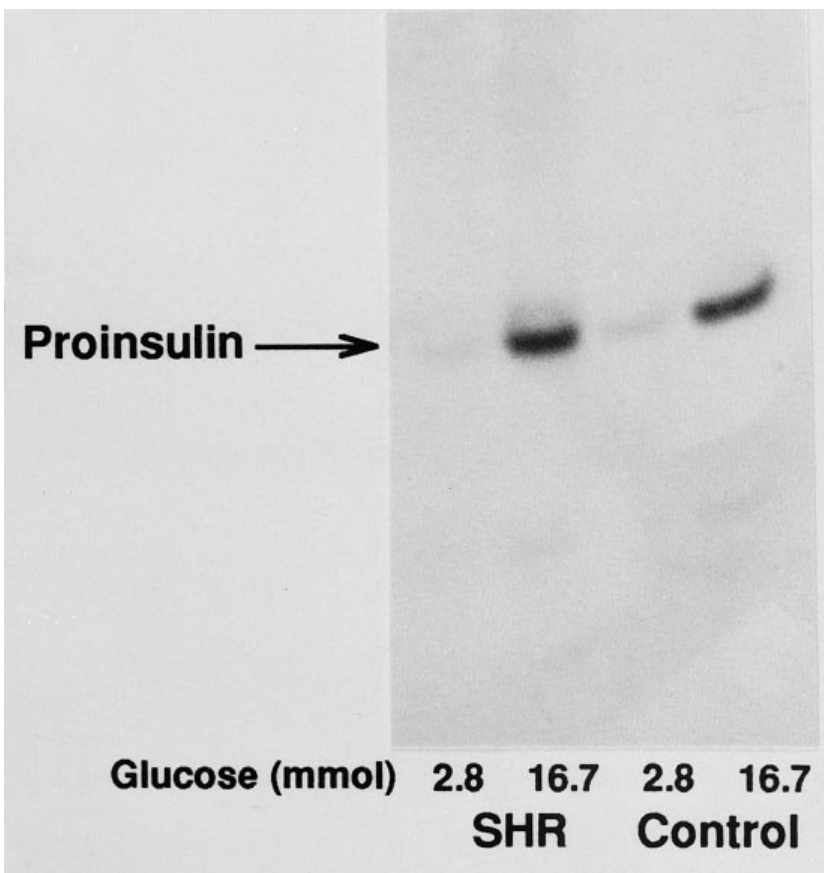

Fig. 2. Proinsulin biosynthesis by $\left[{ }^{35} \mathrm{~S}\right]$ methionine incorporation in freshly isolated islets of SHR and WK rats. Islets (150) were incubated $40 \mathrm{~min}$ at $37^{\circ} \mathrm{C}$ in $100 \mu \mathrm{l}$ modified $\mathrm{KRB}$, $20 \mathrm{mmol} / \mathrm{l} \mathrm{N}$-2-hydroxyethyl piperazine-N'-2ethanesulphonic acid (HEPES), $0.1 \%$ bovine serum albumin (BSA), 2.8 or $16.7 \mathrm{mmol} / \mathrm{l}$ glucose, then radiolabelled $30 \mathrm{~min}$ in $100 \mu \mathrm{l}$ incubation media with the same glucose concentration and $0.25 \mathrm{mCi}\left[{ }^{35} \mathrm{~S}\right] \mathrm{methionine}$. They underwent lysis, immunoprecipitation with anti-insulin serum, alkaline-urea polyacrylamide gel electrophoresis, and fluorography. A pair of bands is shown for each animal: the $2.8 \mathrm{mmol} / \mathrm{l}$ glucose sample is on the left, and $16.7 \mathrm{mmol} / \mathrm{l}$ glucose on the right

Neither of the tested glucose concentrations was physiologic. We repeated the experiment using $7.8 \mathrm{mmol} / \mathrm{l}$ glucose during the incubation and labelling periods. Also, a "chase" period at $2.8 \mathrm{mmol} / \mathrm{l} \mathrm{glu}-$ cose was included after the labelling period to study insulin degradation. In SHR and WK, the band intensity of the newly-formed proinsulin at $1 \mathrm{~h}$ (now insulin) was greater than at $0 \mathrm{~h}$, reflecting additional incorporation of label from intracellular $\left[{ }^{35} \mathrm{~S}\right]$ methionine. Thus, the $1 \mathrm{~h}$ measure was felt to best reflect proinsulin synthesis. Using this measure, a decrease was noted in SHR at $55 \pm 10 \%$ of WK $(n=6, p<0.006)$. Viewed together, the Northern and radiolabel incorporation results showed no increase in proinsulin biosynthesis in SHR islets, and possibly a decrease depending on the in vitro condition studied.

In vivo proinsulin synthesis in SHR. We were concerned that a potentiating factor for proinsulin synthesis was active in SHR that was not apparent during the in vitro testing. To address this issue, proinsulin synthesis was assessed in vivo based on the reports of Permutt, Giddings, and Logothetopoulis [15-17] 
Table 1. In vivo proinsulin biosynthesis in SHR and WK rats

\begin{tabular}{|c|c|c|c|}
\hline & $\begin{array}{l}\text { WK } \\
(n=3)\end{array}$ & $\begin{array}{l}\text { SHR } \\
(n=3)\end{array}$ & $\mathrm{P}$ \\
\hline Weight (g) & $190 \pm 8$ & $198 \pm 9$ & NS \\
\hline $\begin{array}{l}\text { Administered radiolabel } \\
(\mathrm{mCi})\end{array}$ & $2.7 \pm 0.1$ & $2.8 \pm 0.1$ & NS \\
\hline $\begin{array}{l}\text { Serum specific activity } \\
(\mathrm{cpm} / \mu \mathrm{l})\end{array}$ & $25561 \pm 1510$ & $25244 \pm 542$ & NS \\
\hline $\begin{array}{l}\text { Proinsulin activity } \\
(\mathrm{cpm} / \mathrm{ng} \text { IRI) }\end{array}$ & $1.6 \pm 0.2$ & $1.7 \pm 0.1$ & NS \\
\hline Proportion proinsulin (\%) & $7.1 \pm 1.1$ & $4.1 \pm 0.4$ & 0.06 \\
\hline
\end{tabular}

Data are expressed as means \pm SEM. Statistical significance was assessed by the Student's unpaired $t$-test

but with HPLC replacing column chromatography to separate the insulins and proinsulins. Three pairs of nonanesthetized SHR and WK rats were given $\left.1.4 \mathrm{mCi} / 100 \mathrm{~g}{ }^{35} \mathrm{~S}\right]$ methionine through a jugular catheter. After $30 \mathrm{~min}$, the pancreas was excised, homogenized in acid ethanol, and processed for insulin/proinsulin precipitation as described previously [18]. Serum isotope enrichment was determined by liquid scintillation counting. The extracts underwent reverse-phase HPLC using Altex Ultrasphere ODS 420 columns (Beckman, San Ramon, Calif., USA; $4.6 \mathrm{~mm}$ i.d., $10 \mathrm{~cm}$ precolumn and $25 \mathrm{~cm}$ main column). Buffer A: $50 \mathrm{mmol} / \mathrm{l}$ phosphoric acid, $20 \mathrm{mmol} / 1$ triethylamine, $50 \mathrm{mmol} / 1$ sodium perchlorate, $\mathrm{pH}$ 3.0. Buffer $\mathrm{B}$ : $90 \%$ acetonitrile, $10 \% \mathrm{H}_{2} \mathrm{O}$. The programme was a $90 \mathrm{~min}$ gradient from $67.5 \%: 32.5 \%$ buffer $\mathrm{A}: \mathrm{B}$ to $60 \%: 40 \% \mathrm{~A}: \mathrm{B}$. One $\mathrm{ml}$ fractions (flow rate $1 \mathrm{ml} / \mathrm{min}$ ) were collected for insulin RIA and liquid scintillation counting. The insulins eluted at 15-20 min and the proinsulins at 40-45 min. Earlier (30-35 min) and later (48-52 min) RIA peaks were presumed to be conversion intermediates although definitive characterization was not performed. Virtually no $\left[{ }^{35} \mathrm{~S}\right] \mathrm{cpm}$ above the baseline existed in any peak other than proinsulin as expected from the $30 \mathrm{~min}$ time period of the protocol. The calculations made from the HPLC profiles were insulin immunoreactivity (IRI) in the insulin and proinsulin peaks from the RIA results; \% proinsulin = IRI proinsulin $\div$ IRI (proinsulin + insulin); proinsulin activity $=\mathrm{cpm}$ in the proinsulin peak minus background $\div$ IRI proinsulin.

The body weights, administered radiolabel, and serum isotopic enrichment were equal in the SHR and WK rats (Table 1). No difference in proinsulin synthesis was observed between SHR and WK as reflected in similar $\left[{ }^{35} \mathrm{~S}\right]$ activities of the proinsulin peak.

Proinsulin synthesis in SHR: conclusions. Proinsulin synthesis was not increased in SHR based on rigorous in vitro and in vivo assessment. A concern could be that our methods were not sensitive enough to identify a small increase in synthesis. However, it must be emphasized that SHR secrete insulin at twice the normal rate [2], so that a doubling of synthesis (more so, since the insulin stores are increased in SHR islets) would be needed to prevent depletion of the insulin stores which should easily have been observed. Another issue is the large amount of radioactivity needed for the in vivo protocol caused us to use younger animals (8 week-old WK and 10 week-old SHR) than for the rest of the study although this was felt not to be significant since insulin resistance or hyperinsulinaemia or both have been found in 10 weekold SHR $[19,20]$. Thus, our results argue against proinsulin synthesis being the site of compensation in SHR in terms of how the beta-cell insulin stores are maintained. Of great interest, this conclusion disagrees with pregnancy [12], another insulin resistant state, which may reflect the unique factors which mediate the beta-cell compensation in pregnancy: oestrogen, prolactin and placental hormones [4, 21]. Thus, our findings raise the intriguing idea of multiple mechanisms to conserve insulin stores based on the inherent beta-cell compensatory mediators.

Intracellular insulin degradation in SHR islets. We also investigated intracellular degradation of insulin granules in SHR islets. The first direct evidence for this process in beta-cells came from Halban in the early 1980 s. Using "pulse chase" radiolabelling of rat islets, they noted a $41 \%$ decrease in the cellular content of labelled insulin after $24 \mathrm{~h}$. They found $16 \%$ in the media, i.e. had been secreted. The remaining $25 \%$ was unaccounted for [10]. Further evidence was obtained with mannoheptulose, an inhibitor of glucose phosphorylation that blocked insulin synthesis and secretion. Recoverable insulin again fell in islets cultured with mannoheptulose, proving the existence of a third regulatory factor for the insulin stores [22]. Insight was provided by the morphological studies of Schnell which correlated these findings to the presence of secondary lysosomes that contained granule material [23]. A number of factors are known to influence degradation. Most relevant for the current study, it varies inversely with the functional activity of islets, i.e. lowered when insulin secretory function is increased or islet insulin content is reduced or both [22-25]. The glucose concentration also is a regulatory factor independent of its effect on insulin secretion [26]. We thus expected to find the degradation rate was lowered in SHR islets because of the beta-cell hyperfunction.

Insulin degradation was investigated in isolated islets using $\left[{ }^{35} \mathrm{~S}\right]$ methionine incorporation at $7.8 \mathrm{mmol} /$ 1 glucose followed by a "chase" period at $2.8 \mathrm{mmol} / \mathrm{l}$ glucose to minimize secretion of the newly synthesized material. Chase periods up to $12 \mathrm{~h}$ showed a stable band intensity for the labelled insulin in both 
groups, consistent with minimal degradation, and with no obvious difference between the SHR and WK islets. However, the correctness of this finding for the in vivo state is clearly open to question, since assessment of the degradation rate entailed studying islets ex vivo for multiple hours at a subphysiologic glucose concentration which artifactually lowered the degradation rate to virtually zero [26]. As such, confirmation of our results awaits development of more physiologically relevant measures for intracellular degradation.

Lowered proinsulin to insulin ratio in SHR. A well recognized finding in diabetic states is a raised serum ratio of proinsulin to insulin [27]. We previously investigated diabetic rats, and found pancreas extracts also had a raised proinsulin to insulin ratio $[18,28]$ which we suggested highlighted the importance of the stored material for determining what is secreted. Table 1 shows a lowered pancreas \% proinsulin in SHR that nearly achieved statistical significance $(p=0.06)$. That result supports our prior conclusion, since a lowered serum proinsulin to insulin ratio has been reported in nondiabetic insulin resistant states such as obesity $[29,30]$. Thus, our results focus attention on disordered storage rather than secretory mechanisms per se mediating the altered serum proinsulin to insulin ratio in different metabolic states.

Conclusions. Proinsulin synthesis was unchanged in SHR based on rigorous in vitro and in vivo assessment. Also, intracellular granule degradation was not obviously changed within the limits of current technology. We thus lack an explanation as to how the insulin stores are preserved in these hyperinsulinaemic rats. The current understanding of beta-cell physiology is based on the dogma that a coordinated balance of insulin production, secretion and degradation underlies the regulation of stored insulin. The current results suggest that additional regulatory factors may be operative in insulin resistant states, with the intracellular trafficking, targeting, and storage of granules being potential regulatory sites that affect granule life span.

Acknowledgements. This work was supported by National Institutes of Health grants DK-36836 (JLL) and DK 50610 (CJR).

\section{References}

1. Kahn SE, Prigeon RL, McCulloch DK et al. (1993) Quantification of the relationship between insulin sensitivity and $\beta$-cell function in human subjects. Evidence for a hyperbolic function. Diabetes 42: 1663-1672

2. Chen C, Hosokawa H, Bumbalo LM, Leahy JL (1994) Mechanism of compensatory hyperinsulinemia in nor- moglycemic insulin resistant SHR rats: augmented enzymatic activity of glucokinase in $\beta$-cells. J Clin Invest 94: 399-404

3. Green IC, Taylor KW (1972) Effects of pregnancy in the rat on the size and insulin secretory response of the islets of Langerhans. J Endocr 54: 317-325

4. Parsons JA, Brelje TC, Sorenson RL (1992) Adaption of islets of Langerhans to pregnancy: increased islet cell proliferation and insulin secretion correlates with the onset of placental lactogen secretion. Endocrinology 130: 1459-1466

5. Polonsky KS, Given BD, Hirsch L et al. (1988) Quantitative study of insulin secretion and clearance in normal and obese subjects. J Clin Invest 81: 435-441

6. Leahy JL (1996) $\beta$-cell dysfunction with chronic hyperglycemia: the "overworked $\beta$-cell" hypothesis. Diabetes Revs 4: 298-319

7. Hosokawa YA, Leahy JL (1997) Parallel reduction of pancreas insulin content and insulin secretion in 48-h tolbutamide-infused normoglycemic rats. Diabetes 46: 808-813

8. Iwase M, Nunoi K, Kikuchi M et al. (1989) Morphometrical and biochemical differences of endocrine pancreata between spontaneously hypertensive and normotensive rats with or without streptozotocin-induced diabetes. Lab Invest 60: 102-105

9. Itoh N, Okamota H (1980) Translational control of proinsulin synthesis by glucose. Nature 283: 100-102

10. Halban PA, Wollheim CB (1980) Intracellular degradation of insulin stores by rat pancreatic islets in vitro: an alternative pathway for homeostasis of pancreatic insulin content. J Biol Chem 255: 6003-6006

11. Hutton JC, Bailyes EM, Rhodes CJ, Rutherford NG, Arden SD, Guest PC (1990) Biosynthesis and storage of insulin. Biochem Soc Trans 18: 122-124

12. Bone AJ, Taylor KW (1976) Metabolic adaption to pregnancy shown by increased biosynthesis of insulin in islets of Langerhans isolated from pregnant rats. Nature 262: 501-502

13. Hosokawa YA, Hosokawa H, Chen C, Leahy JL (1996) Mechanism of impaired glucose potentiated insulin secretion in diabetic $90 \%$ pancreatectomy rats: study using GLP-1 (7-37). J Clin Invest 97: 180-186

14. Alarcón C, Leahy JL, Schuppin GT, Rhodes CJ (1995) Increased secretory demand rather than a defect in the proinsulin conversion mechanism causes hyperproinsulinemia in a glucose-infusion rat model of non insulin dependent diabetes mellitus. J Clin Invest 95: 1032-1039

15. Permutt MA, Kakita K, Malinas P et al. (1984) An in vivo analysis of pancreatic protein and insulin biosynthesis in a rat model for non-insulin-dependent diabetes. J Clin Invest 73: $1344-1350$

16. Giddings SJ, Orland MJ, Weir GC, Bonner-Weir S, Permutt MA (1985) Impaired insulin biosynthetic capacity in a rat model for non-insulin-dependent diabetes. Studies with dexamethasone. Diabetes 34: 235-240

17. Logothetopoulis J, Jain K (1980) In vivo incorporation of $\left[{ }^{3} \mathrm{H}\right]$ leucine and $\left[{ }^{3} \mathrm{H}\right]$ tryptophan into proinsulin-insulin and other islet cell proteins in normoglycemic, hyperglycemic, and hypoglycemic rats. Diabetes 29: 801-805

18. Leahy JL (1993) Increased proinsulin/insulin ratio in pancreas extracts of hyperglycemic rats. Diabetes 42: 22-27

19. Mondon CE, Reaven GM (1988) Evidence of abnormalities of insulin metabolism in rats with spontaneous hypertension. Metabolism 37: 303-305

20. Xu G, Tanigawa K, Nakamura S, Kawaguchi M, Kato Y, Tamura K (1995) $\beta$-cell function and replication in spontaneously hypertensive rats. Metabolism 44: 1360-1364 
21. Weinhaus AJ, Stout LE, Sorenson RL (1996) Glucokinase, hexokinase, glucose transporter 2, and glucose metabolism in islets during pregnancy and prolactin-treated islets in vitro: mechanisms for long term up-regulation of islets. Endocrinology 137: 1640-1649

22. Halban PA, Wollheim CB, Blondel B, Renold AE (1980) Long-term exposure of isolated pancreatic islets to mannoheptulose: evidence for insulin degradation in the $\beta$ cell. Biochem Pharmacol 29: 2625-2633

23. Schnell AH, Swenne I, Borg LAH (1988) Lysosomes and pancreatic islet function. A quantitative estimation of crinophagy in the mouse pancreatic $\beta$-cell. Cell Tissue Res 252: 9-15

24. Schnell Landström AH, Andersson A, Borg LAH (1991) Lysosomes and pancreatic islet function: adaptions of $\beta$ cell lysosomes to various metabolic demands. Metabolism 40: 399-405

25. Halban PA, Renold AE (1983) Influence of glucose on insulin handling by rat islets in culture: a reflection of integrated changes in insulin biosynthesis, release, and intracellular degradation. Diabetes 32: 254-261
26. Schäfer G, Daum H, Schatz H (1983) Studies on insulin degradation inside the pancreatic B-cell: evidence for a regulating role of glucose. Mol Cell Endocrinol 31: 141-149

27. Rhodes CJ, Alarcón C (1994) What beta-cell defect could lead to hyperproinsulinemia in NIDDM? Some clues from recent advances made in understanding the proinsulin-processing mechanism. Diabetes 43: 511-517

28. Leahy JL, Halban PA, Weir GC (1991) Relative hypersecretion of proinsulin in a rat model of non-insulin-dependent diabetes mellitus. Diabetes 40: 985-989

29. Koivisto VA, Yki-Järvinen H, Hartling SV, Pelkonen R (1986) The effect of exogenous hyperinsulinemia on proinsulin secretion in normal man, obese subjects, and patients with insulinoma. J Clin Endocrinol Metab 63: 1117-1120

30. Saad MF, Kahn SE, Nelson RG et al. (1990) Disproportionately elevated proinsulin in Pima Indians with noninsulin-dependent diabetes mellitus. J Clin Endocrinol Metab 70: $1247-1253$ 